\title{
EREBEA
}

Revista de Humanidades y Ciencias Sociales

Núm. 10 (2020), pp. 85-110

ISSN: 0214-0691

http://dx.doi.org/10.33776/erebea.v10i0.4961

\section{Contextual and Individual Predictors of Bullying and Victimization in Slovenia: Positive Youth Development Perspective}

\author{
Ana Kozina \\ Tina Pivec \\ Educational Research Institute, Gerbičeva 62, 1000 Ljubljana, Slovenia
}

Abstract

Bullying and victimization pose a serious risk for youth optimal development due to numerous negative short- and longterm consequences. One of the models with a focus on adolescents that can serve as a theoretical framework in designing prevention and intervention programmes targeting bullying and victimization is Positive Youth Development Perspective. The Positive Youth Development perspective assumes that with the positive interplay between developmental assets (internal and external youth resources) and the 5Cs (competence, confidence, character, caring, connection) the probability of bullying and victimization lowers. In the present study, we have investigated the predictive power of developmental assets and the 5Cs for bullying (verbal and social bullying) and victimization (verbal and social victimization) on a sample of older adolescents and emerging adults $(N=434$, $80.9 \%$ girls, $\left.M_{\text {age }}=21.65\right)$. We used The Developmental Assets Profile (Benson, 2003), PYD questionnaire (Geldhof et al., 2014) and Adolescent Peer Relations Instrument: Bully/Target (APRI-BT,

\section{Resumen}

El acoso y la victimización suponen un grave riesgo para el desarrollo óptimo de los jóvenes debido a numerosas consecuencias negativas a corto y a largo plazo. Uno de los modelos con enfoque en la adolescencia que puede servir como marco teórico en el diseńo de programas de prevención e intervención dirigidos al acoso y la victimización es la perspectiva de Desarrollo Positivo Juvenil (DPJ). La perspectiva del DPJ asume que con la interacción positiva entre los activos del desarrollo (recursos juveniles internos y externos) y las 5Cs (competencia, confianza, carácter, cuidado, y conexión), la probabilidad de acoso y victimización disminuye. En el presente estudio, se ha investigado el poder predictivo de los activos del desarrollo y las 5Cs para el acoso (tanto verbal como social) y la victimización (tanto verbal como social) en una muestra de adolescentes tardíos $\mathrm{y}$ adultos emergentes $(\mathrm{N}=434,80,9 \%$ niñas,$M$ edad $=21,65)$. Se administró el The Developmental Assets Profile (Benson, 2003), el cuestionario de DPJ (Geldhof et al., 2014) y el Adolescent Peer Relations Instrument: Bully / Target (APRI-BT, 
Marsh et al., 2011). The findings show that gender, age, and Caring are significant predictors of Verbal bullying while age, Empowerment, and Caring are significant predictors of Social bullying. Furthermore, gender, age, Constructive use of time, Confidence and Connection are significant predictors of Verbal victimization and age, Empowerment, Constructive use of time, Confidence, and Connection are significant predictors of Social victimization. The implications for practice and future research are discussed.

\section{KEYWORDS}

Bullying; victimization; Positive Youth Development; Slovenia

Fecha de recepción: 24 de septiembre de 2020 Fecha de aceptación: 26 de octubre de 2020
Marsh et al., 2011). Los resultados indicaron que el género, la edad y el cuidado son predictores significativos del acoso verbal, mientras que la edad, el empoderamiento y el cuidado son predictores importantes del acoso social. Además, el género, la edad, el uso constructivo del tiempo, la confianza y la conexión son predictores significativos de la victimización verbal, y la edad, el empoderamiento, el uso constructivo del tiempo, la confianza y la conexión son predictores significativos de la victimización social. Se han discutido las implicaciones para la práctica y la investigación futura.

\section{Palabras Clave \\ Acoso escolar; victimización; desarrollo positivo juvenil; Eslovenia}




\section{INTRODUCTION}

As it was widely researched, bullying and victimization may be a serious threat for youth optimal development due to numerous negative short- and long-term consequences (e.g., Juvonen \& Graham, 2014; Moore et al., 2017), especially during adolescence (Card, Stucky, Sawalani, \& Little, 2008). Not only does bullying have several negative consequences at the individual level, but it also has a negative impact on processes within the school (e.g., school climate, school connectedness, teaching practices) (Brookmeyer, Fanti, \& Henrich, 2006; Malm \& Löfgren, 2006). Therefore, research on possible protective factors for bullying and victimization is in need. To enhance the effectiveness of the bullying prevention and intervention programs theoretical sound models with clear links between protective factors and outcomes need to be considered.

Bullying was initially defined as a student's exposure to aggressive behaviour over a long period caused by his peer or a group of peers (Olweus, 1997). In the past 40 years of bullying research, several definitions were used. In an overview, we can identify the following common features of bullying (Salmivalli $\&$ Peets, 2009): the purpose of violence is to harm, the bullying perpetration lasts for longer periods, and there is a difference in power between the bully and the victim. In this direction, contemporary definitions describe bullying as a goal-directed behaviour that harms another individual in the context of power imbalance (Volk, Veenstra, \& Espelage, 2017), as researchers assume that even a single event can be very harmful to an individual and bullying behaviour doesn't need to be repeated over time. There are several types of bullying, such as physical bullying (e.g., hitting, kicking, pushing), verbal bullying (e.g., insults, threats), social bullying (e.g., social exclusion, rumours) (Marsh et al., 2011; Menesini \& Salmivalli, 2017) and cyberbullying (Slonje \& Smith, 2008). On the other side, victimization is similarly defined as an exposure to negative actions (i.e., bullying) repeatedly and over time from an individual or a group of people and includes the imbalance in power between the bully and the victim (Olweus, 1997). Similar to bullying, four main types of victimization are recognized: physical victimization, verbal victimization, social victimization, and cybervictimization (Marsh et al., 2011). For late adolescents and emerging adults verbal and social bullying and verbal and social victimization are more frequent as opposed to physical and cyber bullying (Pontzer, 2010). Victimization is associated with several negative 
outcomes, such as mental health difficulties (e.g., depression, anxiety), and selfharming behaviour (Moore et al., 2017), while bullying perpetration is associated with negative outcomes as well, including a higher risk of drug abuse, school adjustment problems, and the occurrence of mental health issues (Nansel, Craig, Overpeck, Saluja, \& Ruan, 2004).

To plan effective prevention and intervention of bullying and victimization, an in-depth understanding of the phenomenon and factors contributing to its prevalence is needed. Bullying and victimization are complex social phenomenona, as they involve a whole group of peers (Salmivalli, Lagerspetz, Bjorkqvist, \& Osterman, 1996), so the factors influencing bullying and victimisation can be divided into three levels: school level (e.g., school climate; Gendron, Williams, \& Guerra, 2011), class level (e.g., class norms concerning bullying and victimization; (Salmivalli, Voeten, \& Poskiparta, 2011) and individual level (e.g., perceived peer support; Košir et al., 2019). Although predictors on all three levels are important when considering bullying and victimization, predictors on the individual level are the strongest ones (Saarento, Kärnä, Hodges, \& Salmivalli, 2013). Research examining the factors of bullying divided the factors at all three mentioned levels into protective factors and risk factors. A meta-analytical study of protective factors (Ttofi, Bowes, Farrington, \& Lösel, 2014) showed that factors such as academic achievement, social skills, attachment to parents, and being friends with students who behave prosocially reduce bullying. Furthermore, a review of meta-analytical research shows that factors such as high social status, high peer support, and higher self-esteem are associated with lower levels of victimization (Zych, Farrington, \& T tofi, 2019). Regarding protective factors of bullying, they were found to include high levels of peer support, high self-esteem, high levels of empathy, good social skills, high levels of self-awareness and social awareness (Zych, Farrington, \& Ttofi., 2019).

One of the models with a focus on adolescents that can serve as a theoretical framework in designing prevention and intervention programmes targeting bullying and victimization is Positive Youth Development perspective (Lerner, 2007). This paradigm addresses adolescent development with an emphasis on strengths rather than deficits (Catalano, Berglund, Ryan, Lonczak, \& Hawkins, 2004) and views positive development as a product of the interaction between an active, engaged and competent person and a receptive, supportive and nurturing ecology (e.g., developmental assets; Damon, 2004). It is based on Relational Developmental System Theory (Overton, 2015) that focuses on the importance of the interaction of individual characteristics and their contexts (e.g., school, family, community, society) (Lerner, 2007). Thus, in this interaction, positive youth development outcomes (reflected in the 5Cs of competence, confidence, character, caring and connection) are more probable while risky behaviours (e.g., substance abuse, bullying) are less frequent (Lewin-Bizan et al., 2010). Within 
the paradigm, the role of the contexts to which the adolescent belongs is strongly emphasized and is described as developmental assets.

Development assets are divided into internal and external assets. External assets are defined as support (family support, positive family relationships, other relationships with adults, caring neighbourhood, favourable school climate, parental involvement in schooling), empowerment (community values, helping others, security), boundaries and expectations (boundaries within the family, boundaries within school, boundaries within neighbourhoods, adult role models, positive peer influence, high expectations) and constructive use of time (creative activities, youth programs, religious community, time spent at home). Internal assets include commitment to learning (motivation to succeed, learning commitment, homework, connection to the school, reading for pleasure), positive values (care, equality and social justice, integrity, honesty, responsibility, self-control), social competences (planning and decision-making, interpersonal competencies, cultural competencies, appropriate conflict resolution) and positive identity (self-esteem, positive opinion of personal future) (Benson, 2003; Benson, Scales, \& Syvertsen, 2011). As stated above, the developmental assets are reflected in the indicators of positive youth development, the 5Cs of competence, confidence, character, connection and caring (Bowers et al., 2010). Competence is a positive opinion about one's actions in specific areas (e.g., social competences and learning performance), while Confidence is defined as an inner feeling of positive self-esteem and self-efficacy. Character is viewed as possession of ethical standards of behaviour that are consistent with social and cultural norms. Connection is an intertwining of positive mutual relations of the individual with his or her important others, institutions and communities. Caring is a combination of empathy and compassion.

A higher level of developmental assets is reflected in a higher level of the 5Cs leading to a higher level of individuals' contribution to the contexts they belong to and lower levels of emotional difficulties and risky behaviours (e.g., Pittman, Irby, \& Ferber, 2001). The paradigm of Positive Youth Development includes bullying in the research to a lesser extent, even though bullying is one of the most undesirable and risky behaviours. When looking at the role bullying plays in PYD perspective, two research focuses can be found in the research literature: one is the relationship between developmental assets and bullying and the other is the relationship between the $5 \mathrm{Cs}$ and the bullying. For developmental assets research, a large body of evidence consistently shows that developmental assets contribute to a variety of positive behavioural performance indicators, such as school success, helping others, maintaining physical health, successfully postponing rewards, valuing diversity, and overcoming distress (Leffert et al., 1998; Scales, Benson, Leffert, \& Blyth, 2000), and lower levels of risky behaviour, such as aggression and bullying (Benson \& Scales, 2009). And as far as the 5Cs are concerned, studies 
confirm that the presence of the $5 \mathrm{Cs}$ leads to the contribution of adolescents to the contexts to which they belong (e.g., family, school, peer group) (Lerner et al., 2005; Lewin-Bizan et al., 2010) and are negatively associated with risky behaviour, such as aggression and bullying, and emotional problems (Jelicic, Bobek, Phelps, Lerner, \& Lerner, 2007; Murry, Berkel, Simons, Simons, \& Gibbons, 2014). The research mainly examined the link between developmental assets of PYD and bullying (Benson \& Scales, 2009; Fredkove, Gower, \& Sieving, 2019) or individual indicators of positive youth development (i.e., the $5 \mathrm{Cs}$ ), such as character (Hilliard et al., 2014). In spite the fact that individual predictors of bullying are of the greatest importance (Saarento et al., 2013), it is necessarily to consider all the factors that may influence the individual's behaviour, thoughts, and emotions about bullying and victimization, which can be achieved through incorporating the PYD into the context of bullying and victimization.

The aim of the present study is to discover if developmental assets and the 5Cs are negative predictors of bullying and victimization among older adolescents and emerging adults. We will focus on two types of bullying and victimization which are most frequent in the developmental periods of late adolescence and emerging adulthood (Pontzer, 2010), social and verbal bullying and victimization.

- Firstly, we focus on associations between developmental assets and bullying. As it was previously stated, students who possess multiple internal and external developmental assets, are less involved in the bullying perpetration or victimization (Benson \& Scales, 2009; Fredkove et al., 2019). Thus, development assets can complement the overall strategy for preventing bullying in the school context. Furthermore, it should be noted that in previous research, individual internal assets (e.g., social competence, positive identity; Tsaousis, 2016; Zych, Farrington, \& Ttofi, 2019), as well as external assets (e.g., peer and teacher support; Holt \& Espelage, 2007; Košir et al., 2019), were linked to bullying and victimization. In accordance with these findings, we hypothesize that developmental assets have a protective function of the occurrence of bullying in our sample.

- Secondly, we focus on associations between the 5Cs and bullying. Research shows that the 5 Cs of PYD are negatively associated with bullying. Specific studies found associations between specific $\mathrm{Cs}$ and bullying, e.g. caring (empathy) (Zych, Ttofi, \& Farrington, 2019), connection (peer support, friendship) (Kendrick, Jutengren, \& Stattin, 2012; Košir et al., 2019), competence (academic and social competence) (Jenkins, Demaray, Fredrick, \& Summers, 2016; Kowalski \& Limber, 2013). Based on the studies reviewed we hypothesize that the $5 \mathrm{Cs}$ will be negative predictors of bullying and victimization.

- Additionally, we will investigate age and gender as predictors as well since male students and younger students were more likely to bully others 
(Pontzer, 2010) and male students and younger students were more likely to be victimized (Beran Rinaldi, Bickham, \& Rich, 2012; Pontzer, 2010). We hypothesize that age will be negative predictor of bullying and victimization while being male will positively predict bullying and victimization.

Although both developmental assets and the 5 Cs of positive youth development were included in the research examining the factors of bullying, however, up to our knowledge, they were not jointly included in any of the previous studies. Moreover, the previous research usually included younger adolescents (e.g., Hilliard et al., 2014). Thusly, the present study contributes to the existing literature by including both developmental assets and the 5Cs as predictors of bullying and victimization and by involving older adolescents and emerging adults in the sample.

\section{Method}

\section{PARTICIPANTS}

A convenience sample included 434 participants from Slovenia (80.9\% girls, $18.7 \%$ boys, $0.5 \%$ nonbinary persons) with age ranging from 18 to 28 ( $M$ $=21.65$ years; $S D=2.48)$. They were students from the last grades of uppersecondary schools (15.2\%) and university $(84.8 \%)$. Most of the university students attended the BA studies (59.2\%). The majority of the participants $(64.8 \%)$ stated that they had good or excellent grades.

\section{MEASURES}

Developmental assets. Developmental assets were measured using The Developmental Assets Profile (Benson, 2003), which consists of 62 items assessing young people's experience of developmental assets. They are divided into internal and external assets categories. The external assets include Support (e.g., "I have a family that gives me love and support"), Empowerment (e.g., "I feel valued and appreciated by others."), Boundaries and expectations (e.g., "I have friends who set good examples for me."), and Constructive Use of Time (e.g., "I am involved in creative things such as music, theatre or other arts."). The internal assets consist of Commitment to Learning (e.g., "I enjoy learning."), Positive Values (e.g. "I tell other people what I believe in."), Social Competencies (e.g., "I accept people who are different from me."), and Positive Identity (e.g., "I am sensitive to the needs and feelings of others."). The participants replied to what extent certain item refers to themselves or their relations with family, friends, and other people in their contexts on the 4-point scale $(1=$ Not at all or rarely, $4=$ Extremely or almost always). Most of the scales had adequate reliability: Support (.74), Empowerment (.70), Boundaries and expectations (.71), Constructive use of time (.47), Commitment to learning (.71), Positive values (.78), Social competencies (.72), and Positive identity (.78). The reported reliabilities are 
consistent with previous studies (Scales, 2011). ESEM (Exploratory Structural Equation Modeling) showed an adequate fit of the 8-factor structure: $X^{2}$ (1609) $=2480.38, p<.001$, RMSEA (Root Mean Square Error of Approximation) $=$ $.037,90 \%$ CI [.034, .040], CFI (Comparative Fit Index) $=.900$, SRMR $=.047$.

The 5 Cs. The 5 Cs were measured by the PYD questionnaire (Geldhof et al., 2014), which consists of 34 items answered on a 5-point Likert scale (with responses ranging from $1=$ strongly disagree to $5=$ strongly agree). The items measure the 5Cs: Competence (e.g., "I do very well in my classwork at school."), Confidence (e.g., "All in all, I am glad I am me."), Caring (e.g., "When I see another person who is hurt or upset, I feel sorry for them."), Character (e.g., "I hardly ever do things I know I shouldn't do."), and Connection (e.g., "My friends care about me."). The questionnaire has proven to be psychometrically adequate (Geldhof et al., 2014). The Slovene version of questionnaire has proven to be psychometrically adequate with reliability coefficients as follows: .67 (Competence); .89 (Confidence); .67 (Character); .81 (Caring); .77 (Connection). CFA (Confirmatory Factor Analyses) confirmed an adequate fit of the 5-factor structure: $\mathrm{X}^{2}(507)=1026.00, p<.001$, RMSEA (Root Mean Square Error of Approximation) $=.051,90 \%$ CI [.046, $.055]$, CFI (Comparative Fit Index) = .904; SRMR $=.063$.

Bullying and victimization. Bullying and victimization were measured by Adolescent Peer Relations Instrument: Bully/Target (APRI-BT, Marsh et al., 2011), which measures bullying and victimization in Verbal, Physical, and Social subdomains. The instrument consists of 36 items and is divided into two parts, bullying and victimization, with 18 items in each part using a 6-point Likert scale (from $1=$ never to $6=$ every day). Every part is further divided into three subdomains (Verbal, Physical, Social) with 6 items. The first part consists of bullying items, where one is asked to assess the frequency of behaviours against other students in the current academic year (e.g., "I teased them by saying things to them" for Verbal bullying, "Pushed or shoved a student" for Physical bullying and "Got other students to ignore a student" for Social bullying). In the second section, one is asked how often these same behaviours had occurred to them (e.g., "I was teased by students saying things to me" for Verbal victimization, "I was pushed or shoved" for Physical victimization and "A student got their friends to turn against me" for Social victimization). Both scales showed high reliability (Verbal bullying: .71, Social bullying: .70, Verbal victimization: 0.87 , Social victimization: .90) and confirmed an adequate fit of the 6-factor structure (including Physical bullying and victimization): $\mathrm{X}^{2}(497)=1563.21$; CFI $=0.90$; RMSEA $=0.07$ CI $[.07, .08]$, SRMR $=.06$.

\section{PROCEDURE}

The present study is a part of a study with aim of investigating longitudinal pathways for positive youth development: Positive Youth Development in 
Slovenia: Developmental Pathways in the Context of Migration (ARRS PYD - SI $M O D E L)$. The instruments used were administered as part of PYD-SI-MODEL measurement battery; the scales used in the present study were administered in the following order: Developmental Assets Profile, Positive Youth Development Questionnaire), Adolescent Peer Relations Instrument: Bully/Target. After obtaining informative consent, the students responded either online $(n=258)$ or on paper $(n=177)$. The time was not limited. On average it took participants about 30 minutes to finish the whole measurement battery.

\section{DATA ANALYSIS}

Out of the total 470 participants, 36 of them were listwise deleted due to having more than $20 \%$ of missing items on each scale. Prior to the analysis, skewness and kurtosis were checked and bullying and victimization did not meet the recommendations since they were positively skewed. According to the Field's recommendations (Field, 2013), all four variables (verbal bullying, social bullying, verbal victimization, social victimization) were logarithmized. Firstly, descriptive statistics and correlations were calculated, furthermore, four linear regressions were utilized to determine the predictive value of demographical variables, developmental assets, and the 5Cs for verbal bullying, social bullying, verbal victimization, and social victimization.

\section{RESULTS}

Descriptive statistics $(M, S D)$ together with correlations are presented in Table 1. The correlation between Verbal and Social bullying was high, as was the correlation between Verbal and Social victimization. The correlation between the verbal forms and social forms of bullying and victimization were moderate, while Verbal bullying and Social victimization were correlated to a low degree while the correlation between Social bullying and Verbal victimization was moderate. Age was negatively correlated with all forms of bullying and victimization, meaning younger emerging adults were more probably bullies than older emerging adults. Developmental assets and the 5Cs were mainly negatively correlated with bullying and victimization except for the internal assets, which were not correlated to both forms of victimization. On the other hand, Competence and Confidence were correlated only with one or both forms of victimization, while Character and Caring were negatively correlated with both forms of bullying. Developmental assets and the 5Cs were positively correlated. 


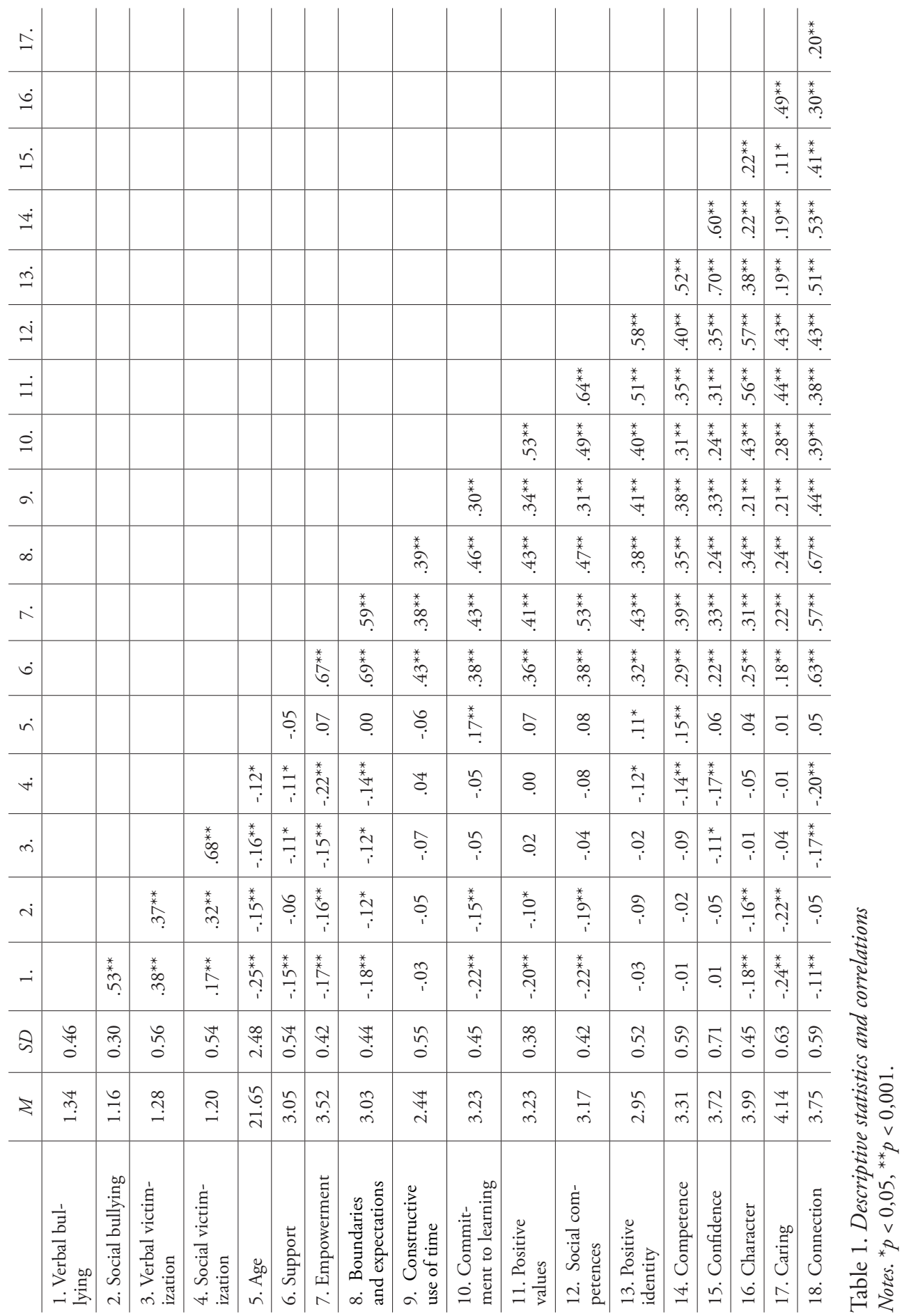


To determine the predictive value of demographic variables (i.e., gender and age), developmental assets and the 5Cs for verbal and social forms of bullying and victimization among adolescents and emerging adults, series of linear regressions were calculated.

\begin{tabular}{c|c|c|c} 
& $B(S E)$ & $B$ & $t$ \\
\hline
\end{tabular}

Verbal bullying $(F(15,417)=7.89, p<.001)$

\begin{tabular}{l|c|c|c}
\multicolumn{5}{|c}{$\mathrm{R}^{2}=.22, \mathrm{R}^{2 *}=.19$} \\
\hline Constant & $.71(.07)$ & & $9.608^{* * *}$ \\
\hline Gender & $-.07(.01)$ & -.23 & $-4.94^{* * *}$ \\
\hline Age & $-.01(.00)$ & -.28 & $-6.14^{* * *}$ \\
\hline Support & $-.01(.02)$ & -.05 & -0.07 \\
\hline Empowerment & $-.01(.02)$ & -.03 & -0.52 \\
\hline Boundaries and expectations & $-.02(.02)$ & -.08 & -1.15 \\
\hline Constructive use of time & $.01(.01)$ & .04 & 0.71 \\
\hline Commitment to learning & $.00(.02)$ & -.01 & -0.23 \\
\hline Positive values & $-.01(.02)$ & -.04 & -0.67 \\
\hline Social competences & $-.03(.02)$ & -.10 & -1.43 \\
\hline Positive identity & $.02(.02)$ & .09 & 1.21 \\
\hline Competence & $.02(.01)$ & .09 & 1.45 \\
\hline Confidence & $.00(.01)$ & .00 & 0.00 \\
\hline Character & $.00(.02)$ & .00 & -0.01 \\
\hline Caring & $-.03(.01)$ & -.14 & $-2.56^{* * *}$ \\
\hline Connection & $.00(.01)$ & -.02 & -0.22
\end{tabular}

Table 2. The predictors (age, gender, developmental assets and 5Cs) of Verbal bullying Notes. ${ }^{*} p<.10{ }^{* *} p<.05 ;{ }^{* * *} p<.001$.

In Table 2, linear regression for Verbal bullying with predictors (gender, age, developmental assets, and the 5Cs) is presented. Age and gender were both significant predictors of Verbal bullying, male gender and younger participants being more likely to act as verbal bullies. Among developmental assets and the 5Cs, Caring was the only significant predictor of Verbal bullying, meaning that participants who care more for others were less likely to be verbal bullies. With selected predictors, we can explain about 19 per cent of Verbal bullying variance. 


\begin{tabular}{|c|c|c|c|}
\hline & $B(S E)$ & $ß$ & $t$ \\
\hline \multicolumn{4}{|c|}{ Social bullying $(F(15,417)=3.552, p<.001)$} \\
\hline \multicolumn{4}{|c|}{$\mathrm{R}^{2}=.11, \mathrm{R}^{2 *}=.08$} \\
\hline Constant & $.36(.06)$ & & $6.27^{* * *}$ \\
\hline Gender & $.00(.01)$ & -.01 & -0.25 \\
\hline Age & $-.01(.00)$ & -.15 & $-3.10^{* *}$ \\
\hline Support & $.01(.01)$ & .08 & 0.99 \\
\hline Empowerment & $-.03(.02)$ & -.15 & $-2.19^{* *}$ \\
\hline Boundaries and expectations & $-.02(.02)$ & -.09 & -1.24 \\
\hline Constructive use of time & $.00(.01)$ & -.02 & -0.26 \\
\hline Commitment to learning & $-.01(.02)$ & -.04 & -0.65 \\
\hline Positive values & $.03(.02)$ & .12 & 1.75 \\
\hline Social competences & $-.02(.02)$ & -.11 & -1.45 \\
\hline Positive identity & $.00(.01)$ & .00 & 0.01 \\
\hline Competence & $.02(.01)$ & .12 & $1.88^{*}$ \\
\hline Confidence & $-.01(.01)$ & -.05 & -0.76 \\
\hline Character & $-.01(.01)$ & -.03 & -0.46 \\
\hline Caring & $-.03(.01)$ & -.19 & $-3.36^{* * *}$ \\
\hline Connection & $.01(.01)$ & .09 & 1.17 \\
\hline
\end{tabular}

Table 3. The predictors (age, gender, developmental assets and 5Cs) of Social bullying Notes. ${ }^{*} p<.10 ;{ }^{* *} p<.05 ;{ }^{* * *} p<.001$.

In Table 3, linear regression for Social bullying is presented. Age was a significant predictor of Social bullying as younger participants being more likely to act as social bullies. Among developmental assets, Empowerment was a negative predictor of Social bullying, therefore participants who felt safe and valued among their family, peers, school, and neighbourhood were less likely to be social bullies. As for the $5 \mathrm{Cs}$, Caring was the only significant predictor of Social bullying, meaning that participants with higher degrees of empathy and sympathy for others being less likely to socially bully others. With selected predictors, we can explain about 8 per cent of Social bullying variance. 


\begin{tabular}{|c|c|c|c|}
\hline & $B(S E)$ & B & $t$ \\
\hline \multicolumn{4}{|c|}{ Verbal victimization $(F(15,417)=3.832, p<.001)$} \\
\hline \multicolumn{4}{|c|}{$\mathrm{R}^{2}=.12, \mathrm{R}^{2 *}=.09$} \\
\hline Constant & $.42(.09)$ & & $4.94^{* * *}$ \\
\hline Gender & $-.03(.02)$ & -.10 & $-2.09^{* *}$ \\
\hline Age & $-.01(.00)$ & -.16 & $-3.20^{* * *}$ \\
\hline Support & $.00(.02)$ & .00 & 0.00 \\
\hline Empowerment & $-.04(.02)$ & -.14 & $-1.98^{*}$ \\
\hline Boundaries and expectations & $-.01(.02)$ & -.04 & -0.57 \\
\hline Constructive use of time & $.04(.01)$ & .18 & $3.23^{* * *}$ \\
\hline Commitment to learning & $.01(.02)$ & .03 & 0.55 \\
\hline Positive values & $.04(.02)$ & .11 & 1.58 \\
\hline Social competences & $.01(.02)$ & .02 & 0.27 \\
\hline Positive identity & $.03(.02)$ & .13 & 1.60 \\
\hline Competence & $.00(.01)$ & .01 & 0.19 \\
\hline Confidence & $-.03(.01)$ & -.17 & $-2.35^{* *}$ \\
\hline Character & $.00(.02)$ & .00 & 0.04 \\
\hline Caring & $-.01(.01)$ & -.05 & -0.95 \\
\hline Connection & $-.04(.02)$ & -.19 & $-2.54^{* *}$ \\
\hline
\end{tabular}

Table 4. The predictors (age, gender, developmental assets and 5Cs) of Verbal victimization Notes. ${ }^{*} p<.10 ;{ }^{* *} p<.05 ;{ }^{* * *} p<.001$.

Among the included predictors of Verbal victimization (see Table 4), age, gender, Constructive use of time, Confidence, and Connection were significant. Age and gender were both significant negative predictors of Verbal victimization, male gender and younger participants being more likely to be verbally victimized. Among developmental assets, Constructive use of time was a positive significant positive predictor, therefore, participants that stated they use their time more constructively were more likely to be verbal victims. As for the $5 \mathrm{Cs}$, Confidence and Connection were significant negative predictors of Verbal victimization, meaning participants with higher levels of Confidence and Connection were less likely to be verbal victims. With selected predictors, we can explain about 9 per cent of Verbal victimization variance. 


\begin{tabular}{|c|c|c|c|}
\hline & $B(S E)$ & B & $t$ \\
\hline \multicolumn{4}{|c|}{ Social victimization $(F(15,417)=3.803, p<.001)$} \\
\hline \multicolumn{4}{|c|}{$\mathrm{R}^{2}=.12, \mathrm{R}^{2 *}=.09$} \\
\hline Constant & $.35(.08)$ & & $4.45^{* * *}$ \\
\hline Gender & $.01(.02)$ & .03 & 0.53 \\
\hline Age & $.00(.00)$ & -.09 & $-1.77^{*}$ \\
\hline Support & $.02(.02)$ & .10 & 1.36 \\
\hline Empowerment & $-.07(.02)$ & -.25 & $-3.63^{* * *}$ \\
\hline Boundaries and expectations & $-.02(.02)$ & -.06 & -0.83 \\
\hline Constructive use of time & $.04(.01)$ & .16 & $2.94^{* *}$ \\
\hline Commitment to learning & $.01(.02)$ & .04 & 0.59 \\
\hline Positive values & $.03(.02)$ & .11 & 1.58 \\
\hline Social competences & $.01(.02)$ & .03 & 0.38 \\
\hline Positive identity & $.01(.02)$ & .04 & 0.48 \\
\hline Competence & $.00(.01)$ & .01 & 0.10 \\
\hline Confidence & $-.03(.01)$ & -.15 & $-2.08^{* *}$ \\
\hline Character & $-.01(.02)$ & -.03 & -0.43 \\
\hline Caring & $.00(.01)$ & -.01 & -0.15 \\
\hline Connection & $-.03(.02)$ & -.16 & $-2.16^{* *}$ \\
\hline
\end{tabular}

Table 5. The predictors (age, gender, developmental assets and 5Cs) of Social victimization Notes. ${ }^{*} p<.10 ;{ }^{* *} p<.05 ;{ }^{* * *} p<.001$.

Similar to Verbal victimization, significant predictors of Social victimization were gender, age, Empowerment, Constructive use of time, Confidence, and Connection (see Table 5). Age was a significant negative predictor of Social victimization, meaning younger participants were more likely social victims. Moreover, male participants were more likely to be socially victimized. Among developmental assets, Empowerment was a negative significant predictor and Constructive use of time was a positive significant predictor of Social victimization. Participants who felt more empowered were less likely to be social victims, while participants who used their time constructively were more likely to be socially victimized. Among the 5Cs, higher levels of Confidence and Connection may prevent participants from being socially victimized. With selected predictors, we can explain about 9 per cent of Social victimization variance. 


\section{Discussion}

In the present study, we have focused on the role bullying and victimization play in the Positive Youth Development perspective (Lerner, 2007) with an underlying motivation that the PYD perspective can serve as a foundation for bullying and victimization prevention and intervention programmes.

In the study, we were interested in the predictive power of the developmental assets for social and verbal bullying and social and verbal victimization separately. Out of all measured assets and for both types of bullying, Empowerment is a significant negative predictor of Social bullying. The more empowered youth is less likely to engage in social or verbal bullying. Scales and Leffert (1999) define empowerment by young people's need to be valued by their community and have opportunities to contribute to others. For this to occur, they must be safe and feel secure. Since the research support for the importance of empowerment in the context of bullying and victimization is lacking (Scales \& Leffert, 1999) our findings present important new insights. Here we can see the important role the contexts play by giving an active role to the youth and trusting in their strengths to contribute. Similarly, Empowerment is a negative predictor of both measured types of victimization, Verbal with 10 per cent risk. The more empowered youth feel less likely it is for them to be victimized. Interestingly, victimization, both Social and Verbal, is positively associated with Constructive use of time. Constructive use of time refers to youth need for constructive, enriching opportunities for growth through creative activities, youth programs, congregational involvement, and quality time at home (Scales \& Leffert, 1999). The more youth is engaged in youth programs and organized activities the more victimized they are. This association is unexpected since we have hypothesized that the more assets one possesses, the less likely it is for her or him to engage in bullying or be victimized. This can be related to the specifics of either sample (convenience sample) or Slovenian context. There are various types of organised youth activities included in the scale Constructive use of time, so this finding is a starting point to investigate further, which specific type of organized youth activity is the one negatively associated with victimization to be able to use this finding in planning prevention and intervention.

Secondly, we were interested in the predictive power of the 5Cs for social and verbal bullying and social and verbal victimization separately. The findings showed that Caring is the only PYD outcome that is a significant negative predictor of both types of bullying. In the PYD perspective, caring is addressed as a combination of empathy and sympathy. There is strong research support of the preventive role of empathy for aggression, especially in adolescents' samples (for a review, see Lovett \& Sheffield, 2007). Empathy enables us to understand others and feel connected with them (Eisenberg, Fabes, \& Murphy, 1996) and has emotional and cognitive components. Emotional empathy is commonly 
interpreted as a response in which the perceived, imagined or inferred emotional state of others produces a similar emotion in the observer. Cognitive empathy, on the other hand, involves the ability to accurately identify the state (i.e. thoughts and feeling) of others. Lack of empathy is associated with many negative effects, e.g., aggression (Ang \& Goh, 2010) and bullying (Estévez, Jiménez, \& Segura, 2019; Gini, Albiero, Benelli, \& Altoè, 2007; Jolliffe \& Farrington, 2006; Stavrinides, Georgiou, \& Theofanous, 2010; Stephan \& Finlay, 1999). Similar findings to ours, involving also aggression types, were reported by Kaukiainen and colleagues (1999) on a sample of early adolescents, that is, empathy is negatively related to social, verbal and physical aggression. The mechanisms that link aggression and empathy are twofold. First, on a cognitive level, when one takes the perspective of another, one can better understand the motives and situation of the other person and thus aggressive behaviour and bullying is less likely to occur (Batanova $\&$ Loukas, 2016; Feshbach, 1987). Second, the other mechanisms that are related to the emotional part of empathy involve the perception of the victim's pain and reduction of aggressive behaviour and bullying in order to avoid pain and suffering in another (Eisenberg \& Fabes, 1990) or to show empathic concern or sympathy towards the other (Eisenberg, Eggum, \& Di Giunta, 2010).

On a level of 10 per cent risk, Competence is also a positive predictor of social bullying. Our assumption would be that the social competence part is especially influencing when it comes to social bullying (Hawley, 2007). As established by Kaukianen and colleagues (1999) indirect (social aggression and social bullying) aggression correlated positively and significantly with social competence across age groups, adolescents included, while physical and verbal forms of aggression had no significant association with social competence. Indirect (social) aggression is behaviour in which the target person is attacked not physically or directly through verbal intimidation but social manipulation. In order to harm someone socially one needs a certain level of social skills and competence (Björkqvist, Lagerspetz, \& Kaukiainen, 1992). Therefore, many authors warn against using social competence programs to prevent aggressive behaviour and bullying. In fact, and also possibly reflected in our sample, social bullying comes hand in hand with social competence. Since social aggression and social bullying increases through the development (Björkqvist, Lagerspetz, \& Kaukiainen, 1992) the findings are especially relevant for our age group. Moreover, imbalance in power is one of the most significant characteristics of bullying behaviour, hence, this additional power gained by socially competent bullies can, without empathy support, be used to harm others instead of helping them.

As for victimization, Confidence and Connection are both negative predictors of both types of victimization. Relating to the confidence, the more confident and connected youth is less probable it is for them to become victims of social or verbal bullying. Even though the negative relationship between confidence 
and victimization has been previously established in terms of self-confidence, self-concept, or self-esteem (e.g., Fanti \& Henrich, 2015; Tsaousis, 2016), it is not yet clear if the experience of victimization leads to the decrease of confidence or it is maybe the other way around as lower confidence can be the reason one is being victimized (Boulton, Smith, \& Cowie, 2010; Fredstrom, Adams, \& Gilman, 2010; van Geel, Goemans, Zwanswijk, Gini, \& Vedder, 2018). At the same time, confidence serves as a protective factor of victimization. Moreover, confidence may buffer victims from negative effects of victimization (Grills \& Ollendick, 2002).

Another significant negative predictor of both types of victimization was Connection. In the PYD perspective, connection is tapping one's numerous positive mutual connections (i.e., family, peers, teachers, neighbours etc.) and is establishing the importance of social networks and being well connected to the various contexts. Our finding is in accordance with the large body of research which consistently shows the protective function of having satisfactory relations with others when it comes to victimization. In the context of victimization, particularly friendship, peer support, teacher support, school climate, and parent support were found to serve protectively in order to reduce or prevent one's experience of victimization (Bollmer, Milich, Harris, \& Maras, 2005; Conners-Burrow, Johnson, Whiteside-Mansell, McKelvey, \& Gargus, 2009; Gage, Prykanowski, \& Larson, 2014; Košir et al., 2019). The overall feeling of being connected to significant others presents a safety net for the individual and, therefore, protects him or her against social and verbal victimization. Furthermore, since bullying and victimization mainly occur in the situations in which other peers are present, having a larger social network and friends who will stand up for him or her can decrease the likelihood of being bullied.

CONCLUSIONS, LIMITATIONS, IMPLICATIONS FOR PRACTICE AND FUTURE RESEARCH

Our study revealed several significant predictors on individual and contexts level that can present a starting point in planning effective bullying and victimisation. Based on our findings, it makes sense to include empathy promotion in aggression and bullying prevention programs. Batanova and Loukas (2016) already showed that programmes targeted at empathy development are important for preventing bullying in early adolescents, which can be also adapted to the older adolescents and emerging adulthood contexts. To include all identified predictors of bullying and victimization, we would suggest empathy-based multicontextual bullying prevention and intervention programmes. Bullying prevention programmes showing promising results are those that are multi-component, multi-contextual (whole-school approach), intensive and long lasting (Leff \& Waasdorp, 2013; Ttofi \& Farrington, 2011). In addition to empathy promotion, contextual resources, such as feeling connected to others, feeling safe and important are 
particularly important and should be emphasized in the context of victimization as well. Moreover, the programmes should tackle one important group which is partially involved in bullying behaviour albeit incredibly important - the bystanders of bullying. The bystander is able to actively intervene to stop the bully, reinforce the bully to continue with his or her actions or view bullying passively (Cowie, 2000). Furthermore, bystanders often believe that bullying is wrong and feel sympathy for victims (Salmivalli, 2010). Based on these findings, the prevention and intervention bullying programmes should address the bullying norms and bystanders' feelings of empathy towards victims while encouraging them to actively intervene. Additionally, we would suggest an extra care in promotion of organized youth activities until it is established in future research which type of organised activities is associated with victimization. In the university contexts, awareness should be raised about the fact that bullying is present on the higher education level as well since it has harmful effects for victims and bullies regardless of age.

Our study has several limitations, since the findings are cross-sectional and the scale Constructive use of time is of low reliability (probably due to numerous activities that are not always connected to one another). The sample that was included was convenient and included participants who filled either online or pencil-paper questionnaire which could affected the results as well. Furthermore, we have used the instruments for measuring bullying and victimization which were not specifically designed for our sample, but for younger ones. Therefore, our findings have to be considered with care and as preliminary. On the other hand, our study has several strengths since we addressed possible protective factors of bullying and victimization on a sample of late adolescents and emerging adults, especially the research regarding bullying and victimization among university students being very limited. Moreover, up to our knowledge, this is the first study that jointly considered developmental assets and the 5Cs when discovering predictors of bullying and victimization. The future studies should consider the transitions between high schools and university contexts to get a deeper understanding of bullying and victimization in this period of time. Furthermore, to identify protective factors longitudinal study designs should be employed together with the questionnaire which will be modified according to bullying behaviours that occur among late adolescents and emerging adults. Finally, there is a need to develop and test the effectiveness of the bullying prevention and intervention programmes in this age group.

\section{ACKNOWLEDgements}

This study was funded by ARRS (the Slovenian Research Agency) (grant number: J5-1781). 


\section{REFERENCES}

Ang, R. P., \& Goh, D. H. (2010). Cyberbullying among adolescents: The role of affective and cognitive empathy, and gender. Child Psychiatry \& Human Development, 41(4), 387-397.

Batanova, M., \& Loukas, A. (2016). Empathy and effortful control effects on early adolescents' aggression: When do students' perceptions of their school climate matter? Journal of Applied Developmental Science, 20, 2, 79-93.

Benson, P. L. (2003). Developmental assets and asset-building community: Conceptual and empirical foundations. In R. M. Lerner \& P. L. Benson (Eds.), Developmental assets and asset-building communities: Implications for research, policy, and practice (pp. 19-43). Boston, MA: Springer.

Benson, P. L., \& Scales, P. C. (2009). Positive youth development and the prevention of youth aggression and violence. International Journal of Developmental Sciences, 3(3), 218-234.

Benson, P. L., Scales, P. C., \& Syvertsen, A. K. (2011). The contribution of the developmental assets framework to positive youth development theory and practice. Advances in Child Development and Behavior 1(41), 197-230.

Beran, T. N., Rinaldi, C., Bickham, D. S., \& Rich, M. (2012). Evidence for the need to support adolescents dealing with harassment and cyber-harassment: Prevalence, progression, and impact. School Psychology International, 33, 562-576.

Björkqvist, K., Lagerspetz, K. M., \& Kaukiainen, A. (1992). Do girls manipulate and boys fight? Developmental trends in regard to direct and indirect aggression. Aggressive Behavior, 18(2), 117-127.

Bollmer, J. M., Milich, R., Harris, M. J., \& Maras, M. A. (2005). A friend in need: The role of friendship quality as a protective factor in peer victimization and bullying. Journal of Interpersonal Violence, 20(6), 701-712.

Boulton, M. J., Smith, P. K., \& Cowie, H. (2010). Short-term longitudinal relationships between children's peer victimization/bullying experiences and self-perceptions: Evidence for reciprocity. School Psychology International, 31(3), 296-311.

Bowers, E. P., Li, Y., Kiely, M. K., Brittian, A., Lerner, J. V., \& Lerner, R. M. (2010). The Five Cs model of positive youth development: A longitudinal analysis of confirmatory factor structure and measurement invariance. Journal of Youth and Adolescence, 39(7), 720-735.

Brookmeyer, K. A., Fanti, K. A., \& Henrich, G. C. (2006). Schools, parents and youth violence: a multilevel ecological analysis. Journal of Clinical Children and Adolescence Psychology, 35, 504-514. 
Card, N. A., Stucky, B. D., Sawalani, G. M., \& Little, T. D. (2008). Direct and indirect aggression during childhood and adolescence: A meta-analytic review of gender differences, intercorrelations, and relations to maladjustment. Child Development, 79(5), 1185-1229.

Catalano, R. F., Berglund, M. L., Ryan, J. A. M., Lonczak, H. S., \& Hawkins, J. D. (2004). Positive Youth Development in the United States: Research Findings on Evaluations of Positive Youth Development Programs. Annals of the American Academy of Political and Social Science, 591(1), 98-124.

Conners-Burrow, N. A., Johnson, D. L., Whiteside-Mansell, L., McKelvey, L., \& Gargus, R. A. (2009). Adults matter: Protecting children from the negative impacts of bullying. Psychology in the Schools, 46(7), 593-604.

Cowie, H. (2000). Bystanding or standing by: Gender issues in coping with bullying in English schools. Aggressive Behavior: Official Journal of the International Society for Research on Aggression, 26(1), 85-97.

Damon, W. (2004). What is positive youth development?. The Annals of the American Academy of Political and Social Science, 591(1), 13-24.

Eisenberg, N., Eggum, N. D., \& Di Giunta, L. (2010). Empathy-related responding: Associations with prosocial behavior, aggression, and intergroup relations. Social Issues and Policy Review, 4(1), 143-180.

Eisenberg, N., \& Fabes, R. A. (1990). Empathy: Conceptualization, measurement, and relation to prosocial behavior. Motivation and Emotion, 14(2), 131-149.

Eisenberg, N., Fabes, R. A., \& Murphy, B. C. (1996). Parents' reactions to children's negative emotions: Relations to children's social competence and comforting behavior. Child Development, 67(5), 2227-2247.

Estévez, E., Jiménez, T., \& Segura, L. (2019). Emotional intelligence and empathy in aggressors and victims of school violence. Journal of Educational Psychology, 111(3), 488.

Fanti, K. A., \& Henrich, C. C. (2015). Effects of self-esteem and narcissism on bullying and victimization during early adolescence. The Journal of Early Adolescence, 35(1), 5-29.

Feshbach, S. (1987). Individual aggression, national attachment, and the search for peace: Psychological perspectives. Aggressive Behavior, 13(5), 315-325.

Field, A. (2013). Discovering statistics using IBM SPSS statistics. London: SAGE.

Fredkove, W. M., Gower, A. L., \& Sieving, R. E. (2019). Association among internal assets, bullying, and emotional distress in eighth grade students. Journal of School Health, 89(11), 883-889. 
Fredstrom, B. K., Adams, R. E., \& Gilman, R. (2010). Electronic and school-based victimization: Unique contexts for adjustment difficulties during adolescence. Journal of Youth and Adolescence, 40(4), 405-415.

Gage, N. A., Prykanowski, D. A., \& Larson, A. (2014). School climate and bullying victimization: A latent class growth model analysis. School Psychology Quarterly, 29(3), 256-271.

Geldhof, J. G., Bowers, E. P., Mueller, K. M., Napolitano, C. M., Schmid Callina, K., \& Lerner, R. M. (2014). Longitudinal analysis of a very short measure of Positive Youth Development. Journal of Youth and Adolescence, 43(6), 933-949.

Gendron, B. P., Williams, K. R., \& Guerra, N. G. (2011). An analysis of bullying among students within schools: Estimating the effects of individual normative beliefs, self-esteem, and school climate. Journal of School Violence, 10(2), 150164.

Gini, G., Albiero, P., Benelli, B., \& Altoè, G. (2007). Does empathy predict adolescents' bullying and defending behavior? Aggressive Behavior, 33(5), 467-476.

Grills, A. E., \& Ollendick, T. H. (2002). Peer victimization, global self-worth, and anxiety in middle school children. Journal of Clinical Child \& Adolescent Psychology, 31, 59-68.

Hawley, P. H. (2007). Social dominance in childhood and adolescence: Why social competence and aggression may go hand in hand. In T. D. Little, P. C. Rodkin, \& P. H. Hawley, Aggression and adaptation: The bright side to bad behavior (pp. 1-29). Lawrence Erlbaum Associates.

Hilliard, L. J., Bowers, E. P., Greenman, K. N., Hershberg, R. M., Geldhof, G. J., Glickman, S. A., ... Lerner, R. M. (2014). Beyond the deficit model: bullying and trajectories of character virtues in adolescence. Journal of Youth and Adolescence, 43(6), 991-1003.

Holt, M. K., \& Espelage, D. L. (2007). Perceived social support among bullies, victims, and bully-victims. Journal of Youth and Adolescence, 36(8), 984-994.

Jelicic, H., Bobek, D. L., Phelps, E., Lerner, R. M., \& Lerner, J. V. (2007). Using positive youth development to predict contribution and risk behaviors in early adolescence: Findings from the first two waves of the 4-H study of positive youth development. International Journal of Behavioral Development, 31(3), 263-273.

Jenkins, L. N., Demaray, M. K., Fredrick, S. S., \& Summers, K. H. (2016). Associations among middle school students' bullying roles and social skills. Journal of School Violence, 15(3), 259-278. 
Jolliffe, D., \& Farrington, D. P. (2006). Examining the relationship between low empathy and bullying. Aggressive Behavior, 32(6), 540-550.

Juvonen, J., \& Graham, S. (2014). Bullying in schools: The power of bullies and the plight of victims. Annual Review of Psychology, 65, 159-185.

Kaukiainen, A., Björkqvist, K., Lagerspetz, K., Österman, K., Salmivalli, C., Rothberg, S., \& Ahlbom, A. (1999). The relationships between social intelligence, empathy, and three types of aggression. Aggressive Behavior: Official Journal of the International Society for Research on Aggression, 25(2), 81-89.

Kendrick, K., Jutengren, G., \& Stattin, H. (2012). The protective role of supportive friends against bullying perpetration and victimization. Journal of Adolescence, 35(4), 1069-1080.

Košir, K., Klasinc, L., Špes, T., Pivec, T., Cankar, G., \& Horvat, M. (2019). Predictors of self-reported and peer-reported victimization and bullying behavior in early adolescents: the role of school, classroom, and individual factors. European Journal of Psychology of Education, 1-22.

Kowalski, R. M., \& Limber, S. P. (2013). Psychological, physical, and academic correlates of cyberbullying and traditional bullying. Journal of Adolescent Health, 53(1), 13-20.

Leff, S. S., \& Waasdorp, T. E. (2013). Effect of aggression and bullying on children and adolescents: implications for prevention and intervention. Current Psychiatry Reports, 15(3), 343.

Leffert, N., Benson, P. L., Scales, P. C., Sharma, A. R., Drake, D. R., \& Blyth, D. A. (1998). Developmental assets: Measurement and prediction of risk behaviors among adolescents. Applied Developmental Science, 2(4), 209-230.

Lerner, R. M. (2007). The good teen. New York, NY, ZDA: The Stonesong Press. Lerner, R. M., Lerner, J. V., Almerigi, J. B., Theokas, C., Phelps, E., Gestsdottir, S., ... Von Eye, A. (2005). Positive youth development, participation in community youth development programs, and community contributions of fifth-grade adolescents: Findings from the first wave of the 4- $\mathrm{H}$ study of positive youth development. Journal of Early Adolescence, 25(1), 17-71.

Lewin-Bizan, S., Lynch, A. D., Fay, K., Schmid, K., McPherran, C., Lerner, J. V., \& Lerner, R. M. (2010). Trajectories of positive and negative behaviors from early- to middle-adolescence. Journal of Youth and Adolescence, 39(7), 751-763.

Lovett, B. J., \& Sheffield, R. A. (2007). Affective empathy deficits in aggressive children and adolescents: A critical review. Clinical Psychology Review, 27(1), 1-13. 
Malm, B., \& Löfgren, H. (2006). Teacher competence and students' conflict handling strategies. Research in Education, 76(1), 62-73.

Marsh, H. W., Nagengast, B., Morin, A. J. S., Parada, R. H., Craven, R. G., \& Hamilton, L. R. (2011). Construct validity of the multidimensional structure of bullying and victimization: An application of exploratory structural equation modeling. Journal of Educational Psychology, 103(3), 701-732.

Menesini, E., \& Salmivalli, C. (2017). Bullying in schools: the state of knowledge and effective interventions. Psychology, Health and Medicine, 22, 240-253.

Moore, S. E., Norman, R. E., Suetani, S., Thomas, H. J., Sly, P. D., \& Scott, J. G. (2017). Consequences of bullying victimization in childhood and adolescence: A systematic review and meta-analysis. World Journal of Psychiatry, 7(1), 60.

Murry, V. M., Berkel, C., Simons, R. L., Simons, L. G., \& Gibbons, F. X. (2014). A twelve-year longitudinal analysis of positive youth development among rural African american males. Journal of Research on Adolescence, 24(3), 512-525.

Nansel, T. R., Craig, W., Overpeck, M. D., Saluja, G., \& Ruan, W. J. (2004). Cross-national consistency in the relationship between bullying behaviors and psychosocial adjustment. Archives of Pediatrics and Adolescent Medicine, 158(8), 730-736.

Olweus, D. (1997). Bully/victim problems in school: Facts and intervention. European Journal of Psychology of Education, XII(4), 495-510.

Overton, W. F. (2015). Processes, relations, and relational-developmental-systems. In W. F. Overton, P. C. M. Molenaar, \& R. M. Lerner (Eds.), Handbook of child psychology and developmental science: Theory and method (p. 9-62). John Wiley \& Sons, Inc.

Pittman, K., Irby, M., \& Ferber, T. (2001). Unfinished business: Further reflections on a decade of promoting youth development. In Benson P. L., Pittman K. J. (Eds.) Trends in youth development (pp. 3-50). Boston, MA: Springer.

Pontzer, D. (2010). A theoretical test of bullying behavior: Parenting, personality, and the bully/victim relationship. Journal of Family Violence, 25, 259-273.

Saarento, S., Kärnä, A., Hodges, E. V. E., \& Salmivalli, C. (2013). Student-, classroom-, and school-level risk factors for victimization. Journal of School Psychology, 51(3), 421-434.

Salmivalli, C. (2010). Bullying and the peer group: A review. Aggression and violent behavior, 15(2), 112-120.

Salmivalli, C., Lagerspetz, K., Bjorkqvist, K., \& Osterman, K. (1996). Bullying as a group Process: participant roles and their relations to social status within the group. Aggressive Behavior, 22, 1-15. 
Salmivalli, C., \& Peets, K. (2009). Bullies, victims, and bully-victim relationships in middle childhood and early adolescence. In K. H. Rubin, W. M. Bukowski, $\&$ B. Laursen (Eds.), Social, emotional, and personality development in context. Handbook of peer interactions, relationships, and groups (p. 322-340). The Guilford Press.

Salmivalli, C., Voeten, M., \& Poskiparta, E. (2011). Bystanders matter: Associations between reinforcing, defending, and the frequency of bullying behavior in classrooms. Journal of Clinical Child and Adolescent Psychology, 40(5), 668-676.

Scales, P. C. (2011). Youth developmental assets in global perspective: Results from international adaptations of the developmental assets profile. Child Indicators Research, 4(4), 619-645.

Scales, P. C., Benson, P. L., Leffert, N., \& Blyth, D. A. (2000). Contribution of developmental assets to the prediction of thriving among adolescents. Applied Developmental Science, 4(1), 27-46.

Scales, P. C., \& Leffert, N. (1999). Developmental assets. Minneapolis, MN: Search Institute.

Slonje, R., \& Smith, P. K. (2008). Cyberbullying: Another main type of bullying?: Personality and Social Sciences. Scandinavian Journal of Psychology, 49(2), 147-154.

Stavrinides, P., Georgiou, S., \& Theofanous, V. (2010). Bullying and empathy: a short-term longitudinal investigation. Educational Psychology, 30(7), 793802.

Stephan, W. G., \& Finlay, K. (1999). The role of empathy in improving intergroup relations. Journal of Social Issues, 55(4), 729-743.

Tsaousis, I. (2016). The relationship of self-esteem to bullying perpetration and peer victimization among schoolchildren and adolescents: A meta-analytic review. Aggression and Violent Behavior, 31, 186-199.

Ttofi, M. M., Bowes, L., Farrington, D. P., \& Lösel, F. (2014). Protective factors interrupting the continuity from school bullying to later internalizing and externalizing problems: A systematic review of prospective longitudinal studies. Journal of School Violence, 13(1), 5-38.

Ttofi, M. M., \& Farrington, D. P. (2011). Effectiveness of school-based programs to reduce bullying: A systematic and meta-analytic review. Journal of Experimental Criminology, 7(1), 27-56.

van Geel, M., Goemans, A., Zwaanswijk, W., Gini, G., \& Vedder, P. (2018). Does peer victimization predict low self-esteem, or does low self-esteem predict peer 
victimization? Meta-analyses on longitudinal studies. Developmental Review, 49, 31-40.

Volk, A. A., Veenstra, R., \& Espelage, D. L. (2017). Aggression and Violent Behavior So you want to study bullying? Recommendations to enhance the validity, transparency, and compatibility of bullying research. Aggression and Violent Behavior, 36, 34-43.

Zych, I., Farrington, D. P., \& Ttofi, M. M. (2019). Protective factors against bullying and cyberbullying: A systematic review of meta-analyses. Aggression and Violent Behavior, 45, 4-19.

Zych, I., Ttofi, M. M., \& Farrington, D. P. (2019). Empathy and CallousUnemotional Traits in Different Bullying Roles: A Systematic Review and Meta-Analysis. Trauma, Violence, and Abuse, 20(1), 3-21. 
